\title{
Ground Beetles (Coleoptera, Carabidae) Assemblages Features Formation in Large and Medium Industrial Cities of Russia (The Case Study in Kazan, Kemerovo and Grozny)
}

\section{T A Avtaeva1, R A Sukhodolskaya², N I Eremeeva ${ }^{3}$, T A Gordienko², N P Vodunon², M I Lechieva ${ }^{4}$, Sh A Kushaliev', and K N Kuropyatnik ${ }^{3}$}

${ }^{1} \mathrm{Kh}$. Ibragimov Complex Institute of the Russian Academy of Sciences, Grozny, Russia

${ }^{2}$ Research Institute for Problems of Ecology and Mineral Wealth Use of Tatarstan Academy of Sciences, Kazan, Russia

${ }^{3}$ Kemerovo State University, Kemerovo, Russia

${ }^{4}$ Chechen State University, Grozny, Russia

${ }^{5}$ Chechen State Pedagogical University, Grozny, Russia

Corresponding Author:

T A Avtaeva

avtaeva1971@mail.ru

Received: 25 October 2019

Accepted: 15 November 2019

Published: 25 November 2019

Publishing services provided by Knowledge E

(c) T A Avtaeva et al. This article is distributed under the terms of the Creative Commons

Attribution License, which permits unrestricted use and redistribution provided that the original author and source are credited.

Selection and Peer-review under the responsibility of the AgroSMART 2019 Conference Committee.

\section{Abstract}

The article presents the results of the analysis of the Carabid fauna of three cities: Grozny, Kemerovo, Kazan. It was established that communities of ground beetles clearly respond to varying degrees of recreation by changing the biotopic distribution and ecological structure: the emergence of super dominant species, a decrease in the abundance of zoophages, an increase in the share of stratobionts, and the presence of indicator species.

Keywords: urban landscapes, anthropogenic load, fauna of ground beetles, species diversity, dynamic density

\section{Introduction}

Urban ecosystems differ in several bioclimatic parameters from natural ones. The transformation of urban ecosystems under the influence of anthropogenic pressure leads to changes in the communities of living organisms that inhabit these ecosystems.

Cities combine both conditions like natural habitats and specific conditions associated with human activities. This can not but affect the living organisms inhabiting urban systems. Many of them are very sensitive to changes in environmental parameters, and therefore they are used as bioindicators. This group of organisms includes beetles from the family of ground beetles (Coleoptera, Carabidae). They dominate both in natural and transformed cenoses and make up $58 \%$ or more of the total number of 
herpetobiotic predators. Currently, there is an extensive literature on the characteristics of the population of ground beetles in an urbanized landscape [5--7; 9--12].

The aim of our work was to analyze the dynamics of the carabid fauna in urban landscapes of Kazan, Kemerovo and Grozny. Each of the selected cities has its own environmental problems and is distinguished by a different degree of anthropogenic pressure. In the course of the work it is planned to formulate the general features of the formation of the carabid fauna, as well as the features characteristic of each of the cities studied.

Kazan -- the capital of Tatrastan Republic, a city with a population of 1.1 million people. It is located in the Middle Volga region in the European part of Russia, at the intersection of airlines, railways and highways of all-Russian significance. The average percentage of urban greening is $22.65 \%$ (Program..., 2004). The city is in the flooded area with the waters of the Kuibyshev reservoir, and is saturated with chemical, petrochemical, machine-building and military-industrial enterprises, as well as motor transport and other types of communications. The main environmental problems of Kazan are pollution of the atmosphere, poor quality of the waters of the Volga, Kazanka and other water bodies within the city, insufficient greening of the city, as well as recycling of garbage. The concentration of anthropogenic impact, the specificity of the geographical location and the device surface of the city determined the characteristic environmental situation, in general, more complex than in many large cities of Russia. The chaotic development in the city significantly complicates the ecological situation in Kazan, i.e., there are virtually no plans to maintain continuous corridors of active distribution of wild species of flora and fauna, and no special measures are taken to conserve natural areas that play an important role in the processes of water and air self-purification. The soil cover of the city is represented by all types of soil, with varying degrees of disturbed morphological profile under the influence of anthropogenic transformation. Soil contamination with heavy metals varies widely, but for the most part, the city is rated as acceptable.

The city of Kemerovo is in the zone of high pollution. This is caused by a significant concentration of enterprises of all major industries (chemical, metallurgical, machinebuilding, energy, coal and construction industry) in a relatively small area, close location of industrial complexes to residential areas of the city. Other factors are the orographic heterogeneity and depression of the city with an open exit only to the north-west at prevailing south-westerly winds, unfavorable climatic and meteorological conditions for the dispersion of harmful substances (small evaporation, increased repeatability of weak winds $20--40 \%$ and surface inversions $30--45 \%$ ). The situation is complicated by the action of a number of moments -- the density and number of buildings floors, the 
prevalence of the underlying surface with good thermal conductivity (stone, asphalt, metal), the orientation of the main streets, distorting the wind flow in the surface layer throughout the city, the Tom river Valley. Residential areas are 100--150 m above enterprises, approximately at the level of their pipes. Emissions from industrial facilities are supplemented by emissions from boilers and vehicles. The environmental situation in the Kirovsky and Rudnichny districts is complicated by the fact that the prevailing southwestern winds contribute to the transfer of atmospheric pollutants from the largest industrial hub Zavodsky to nearby territories and the right-bank part of the city, which already have a high technogenic load. A feature of atmospheric pollution in Kemerovo is the atmospheric air pollution of all functional areas along with harmful substances typical for most cities (oxides of nitrogen, sulfur and carbon, soot, formaldehyde, suspended solids), a large amount of substances (benzo (a) pyrene, chlorine, benzene, aniline, dimethylamine, isopropyl alcohol, hydrogen cyanide, etc.), not typical of the atmosphere of other cities. By the qualitative composition of emissions (over 160 harmful impurities), Kemerovo is in the first place among the cities of Kuzbass. The leading air pollutant in Kemerovo is benzo (a) pyrene, the mean annual concentration of which over the five-year period (2014--2018) increased by 2.3 times and the maximum permissible concentration is constantly observed.

A significant problem is the restoration of the territories at the industrial sites of the liquidated enterprises (both at the liquidated mines and chemical enterprises), which are a source of increased danger.

The city of Grozny and its ecological condition are characterized by a number of features, which makes it different from other cities. First, the centenary practice of the oilrefining and oil-extracting industry and the corresponding environmental consequences. Secondly, the infrastructure of the city was destroyed during hostilities and thirdly, illegal fishing and artisanal production of petroleum products. The city was almost completely restored. In the period of the restoration of the republic and in view of the demographic growth, an increase in the building area is observed. In this connection, the area of urban forests has decreased. The modern city of Grozny in its structure has urban buildings, social and business, industrial and engineering, recreational and agricultural zones. During the period from 2003 to 2017, there were changes in the area of the functional zones of the city of Grozny. The residential zone of the city increased by $2 \%$, while the area of agricultural land decreased by $3.3 \%$. The area of the recreation zone increased by $3.3 \%$. This is associated with an increase in the number of parks, squares and other facilities intended for recreation of citizens. According to the standards, green areas should occupy a total of up to $40--50 \%$ of the area of the city. In Grozny, the main 
types of green space are parks, gardens, squares, boulevards, and quarterly and vertical gardening. Then there was a mixture of local native flora with plantings of introduced species [1].

\section{Methods and Materials}

Trapping and recording of ground beetles was carried out using Barber's soil traps (Barber, 1931). As soil traps, plastic cups with a trap hole $75 \mathrm{~mm}$ in diameter were used. As a fixative, $4 \%$ formalin or $5--10 \%$ acetic acid solution was used. The traps were dug into the soil at the surface level and one quarter filled with $4 \%$ formalin solution with a fixative, which was changed once every 10 days. In each biotope there were 10--15 traps. The distance between the traps was 5--10 meters. Manual trapping of ground beetles imago was used as well.

In Kazan, 82 sites were surveyed in seven administrative districts of the city in three zones of anthropogenic impact (industrial, residential, recreational) in 2005--2007. Lawns, meadows, forest belts, places of mass visits (parks and squares), and bushy green areas around the houses were investigated in each of them. In the Sovetsky district of the city, studies were carried out in 2006, 20 sites were surveyed in three zones. 687 individuals were collected were trapped during the research.

In Kemerovo, studies were conducted in 2001--2004, as well as in 2013--2014, 2017-2018. Studies have been conducted in all areas of the city; the most detailed studies were conducted at six sites. Sections 1 and 2 are located in the Zavodskoy district of the city in whose territory the main industrial hub is located -- Zavodsky (an area of 3,060 hectares), characterized by a high concentration of production: SDS Azot JSC, Khimprom LLC, Coke PJSC (coking plant), PO TOKEM LLC, Kemerovo Mechanical Plant, Novo-Kemerovskaya Thermal Power Plant JSC, Kemerovo State District Power Plant. The first plot -- grass-grassy meadows (lawns); located in a public garden near the management of PJSC "Coke" (coke plant), surrounded by trees and shrubs: Siberian rowan, cherry, Hungarian lilac, hanging birch, Siberian linden, elm elm, Siberian spruce, wrinkled wild rose. Lawns are periodically clipped (once every two weeks). Projective cover wass $50-90 \%$. The average height of herbage was $20 \mathrm{~cm}$. In total, there were 23 species of grassy plants, among them 15 ones were synanthropic. The second section was a grassy meadow (dry meadow); It is in the sanitary protection zone of the Zavodsky industrial hub, near SDS Azot JSC. The site is surrounded by plantings of ash-leaved maple, balsam poplar, squat elm. Part of the meadow is occupied by piles of garbage. About 20 years ago there were private houses and gardens at the 
place of the meadows. Currently, the site is not used for economic activities, rarely is visited by people. Despite the high level of air pollution, demutational succession of vegetation cover is actively taking place at the site, followed by the restoration of zoocenoses. Projective cover was $80-100 \%$. The average height of herbage was 80 $\mathrm{cm}$, maximum -- $120 \mathrm{~cm}$. On the site 17 species of grassy plants were found, 12 of them were synanthropic. Atmospheric air pollution index (API) in areas 1 and 2 is rated as very high. The third site was in the central area Kemerovo city, in the residential area, in the square near the Regional Library. Those were meadows of grass-cereals (grass-dandelion-grass, grass-clover-grass) (lawns). They are cut once every two weeks. Projective cover was $70 \%$. The mean height of the grass stand was $20 \mathrm{~cm}$. The species composition of the grass stand was represented by 7 plant species, among them 2 were synanthropic. The air pollution index in the residential zone of the Central District is estimated as high. Plots 4--6 are in a pine forest in the Mine area, in the recreation zone of the city. This meadows grass-cereals (forest meadows). Bor occupies an area of 489 hectares and is a natural complex, preserved within the city of Kemerovo [3]. Boron belongs to the pine grass with the predominance of nettle and Aegopódium podagrária. The main forest-forming species is Scotch pine Pinus sylvestris L. The woody layer is 20--24 m high. The degree of crowns is 0.2--0.7. The grassy layer is well developed, the projective cover is $30--85 \%$. The level of air pollution in the Mine area is the lowest in the city (API does not exceed 5.02). The plots differ in the level of recreational impact. Section 4 is in the southwestern, frequently visited part of boron, where it is allowed to fry kebabs (on barbecues), there are unpaved roads. Since 2015, the entrance to the boron is prohibited, you can only move on foot to this place of rest. People use the whole area for recreation -- they walk and sit on the grass, sometimes they break branches for barbecues, they tear flowers. Bonfires are forbiddent. The degree of recreational impact in general is moderate; locally, in the places of braziers location -- high. Section 5 is in the northeastern part of boron. It is actively used for recreation and sports: there are children's and volleyball courts and a playground with sports equipment. People move (walk, run) mainly along the paths. The degree of recreational impact in general is moderate; locally, at the locations of the children's and volleyball grounds -- high. Section 6 is in the central, little-visited part of boron, where the grass cover is not disturbed. The degree of recreational impact in general is weak.

In the city of Grozny, studies were conducted in 2003 and again fourteen years later in 2017 in order to analyze the changes in the structure of carabids fauna. 5 biotopes were surveyed: the first biotope was a plot on the edge of a suburban forest, later built up with single-storey private buildings. The second section in 2003 was a meadow with minor 
oil stains; by 2017, during the successional processes, it was overgrown with shrubs. The third section is in the Zavodskoy district of the city of Grozny and was characterized by the strongest oil pollution. By 2017, the soil of this site was recultivated, and the site was used for construction. The fourth site in 2003 represented an unauthorized dump of solid waste, which was eliminated, and the site was used for construction. The fifth biotope is the territory of a suburban floodplain forest, part of which was distributed to household and country plots. Landsat satellite images were used to visualize the changes. For a comparative analysis, a time series of images was constructed, which allowed to decipher the features of the model sites for each chrono cut [1].

The following division was adopted: superdominants -- more than $20 \%$; dominants -- more than $5 \%$; subdominants -- 1--5\%; rare -- less than $1 \%$.

\section{Results}

During the study in Grozny 92 species of ground beetles were recorded from 36 genera. In the first section (Fig. 1) in 2003, 272 copies were registered. out of 50 species, whereas in 2017, 32 species were noted, while the number remained high (318 individuals). Due to the cutting and development of the site, there was a reduction in species diversity, while the high numbers remain due to the dominance of eurytopic species. In the first section in $2003,50 \%$ were ground beetles of the steppe group, $24 \%$ the forest group, $20 \%$-- meadow and $6 \%$ were from near-water group. In the collections of 2017, ground beetles of the steppe group (62 \%) and meadow (31\%) prevailed. While forest and near-water species accounted for $3 \%$. Thus, during deforestation and development there was a reduction in species diversity due to the loss of forest and near-water species. At the same time, steppe and field species dominate, that is, open areas types.
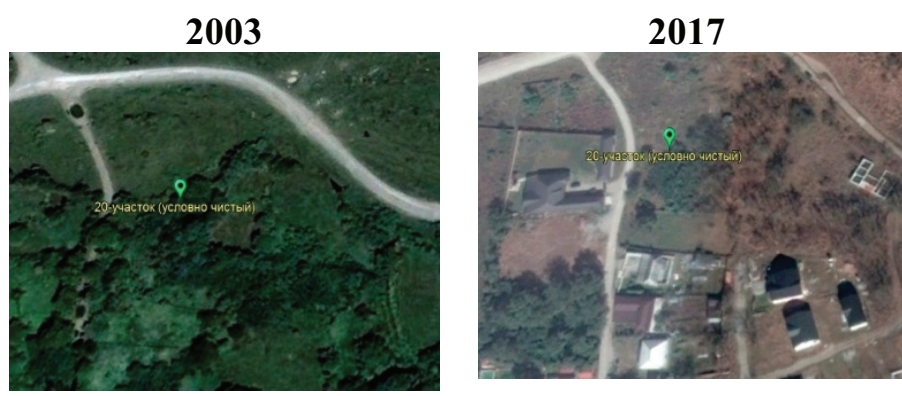

Figure 1: Plot of suburban forest, which was used for building in Grozniy.

The second section in 2003 was a meadow with oil spots, formed as a result of an unauthorized tie-in to the pipeline. Vegetation was represented by meadow-steppe 
communities (Fig. 2). For 14 years as a result of succession processes, the site has been overgrown with dense shrubs dominated by Rosa canina L. Shrub plantings affect the change in air temperature on the soil surface and in the layer up to $30 \mathrm{~cm}$, the humidity that forms the microclimate of the territory. In summer, the temperature of the earth's surface does not reach such values as in the steppe due to the reflection of the sun's rays by the green leaf surface of shrubs. According to a 2003 survey, steppe species dominated in the area and the most numerous were representatives of the genus Harpalus. As a result of the biotope transformation, there was a change of steppe species to mesophilic species of ground beetles belonging to the meadow group. At the same time, the number of species increased: in 2003, 33 species were recorded, in 2017 -- 43 species, the number practically did not change. In 2003, the species of the steppe group amounted to $65 \%$, the meadow group -- $24 \%$; forest -- 9.4 \%. In 2017, 50 \% were meadow species; $12.5 \%$-- forest and $37.5 \%$-- steppe groups. Meadow group species dominated in numbers due to the meadow Poecilus cupreus $L$, 1758 and Calathus distinguendus Chaudoir,1846, as well as the meadow field species Amara aenea DeGeer, 1774 and Harpalus affinis Schrank, 1781.
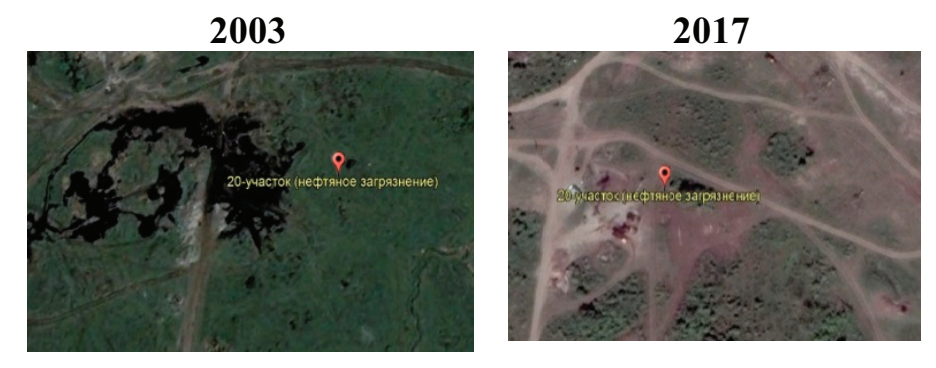

Figure 2: Oil polluted area overgrown with shrubs in Grozhiy.

The third site was in the Zavodskoy district of Grozny city and in 2003 it was heavily polluted by oil spills. In the course of restoration work in the Zavodskoy district, a pit was dug for storing highly contaminated soil, into which polluted soil was brought. When filling the pit, the upper part han been left empty and subsequently had been filled with clean soil removed from the pit. The territory thus cleared was used for building. Due to the significant anthropogenic load, the territory does not differ in the species diversity of ground beetles. In 2003, 15 species were recorded on the site, and in 2017 only 20 species were noted. At the same time, the number in 2017 increased by almost $50 \%$. In 2003, Pterostichus fornicates Kolenati, 1845 dominated. In 2017, the group of dominant species included Poecilus cupreus, P. fornicatus, Calathus distinguendus. Analysis of ground beetle biotopic groups showed that in 2003 steppe group accounted for 76.7 $\%$, meadow -- $22.2 \%$. In 2017, ground beetles of the steppe one accounted for $60 \%$, and meadow grassland $40 \%$. 
For several years, an unauthorized dumping of municipal solid waste was located on the territory of site 4. During the period of liquidation of unauthorized dumps, the garbage was removed, and the territory was filled up with soil. In the future, the site was used for construction (Fig. 4). In 2003, 42 species were registered, and in 2017 it was reduced to 31 species. Eurytopic ruderal species dominated at the landfill, the number of zoophages of litter stratobionts and large epigeobionts was decreasing. When building one-story houses on the studied site, the islands of meadow vegetation remain fragmentary, and there are lawns with loose soil. This makes habitat conditions more diverse. The number of adults increases in comparison with 2003.

2003
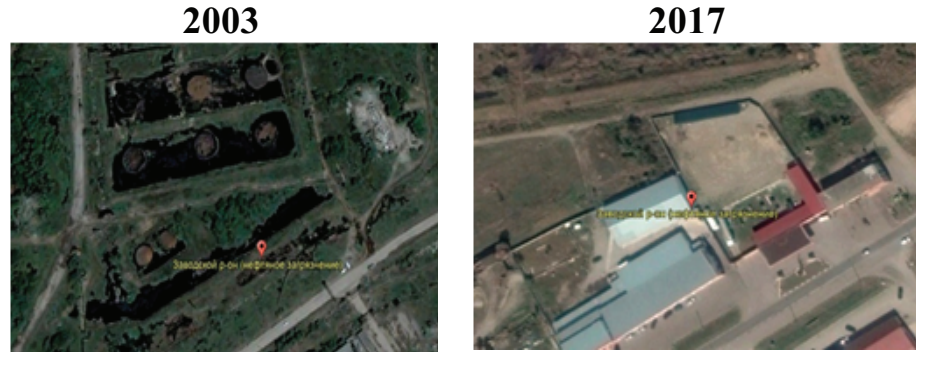

Figure 3: The site cleared of oil pollution is used under building.

By 2017, the percentage of meadow mesophilic species is increasing and the percentage of steppe species is decreasing.

The fifth section is a suburban floodplain forest, part of the land of which is used for construction (Fig. 5). In 2003, 73 species with 1086 specimens of ground beetles imago were recorded on the site. Due to the increased anthropogenic load, there was a reduction in species diversity. The number of dominants, catchability, the abundance of forest stenotopic, hygrophilic and mesohygrophilic, large and rare species, zoophages, among which the proportion of litter stratobionts and large epigeobionts decrease.Tthe abundance of eurytopic and meadow field and steppe species, litter-soil stratobionts and myxophytophages increased accordingly. The ecological structure is characterized by a significant predominance of open space species. Eurytopic species played an important role in numbers.
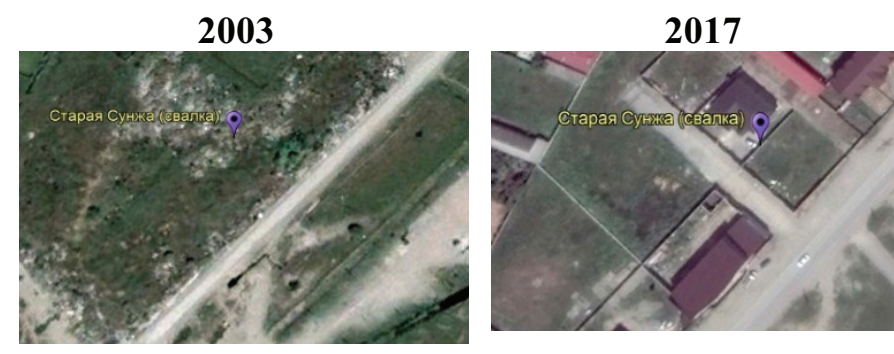

Figure 4: Plot with unauthorized dumping of solid waste, used for construction in Grozniy. 


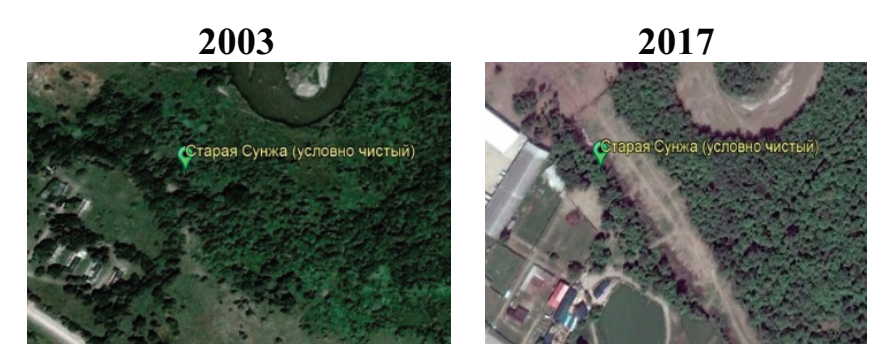

Figure 5: Grozny suburban forest.

In total, 93 species of 33 genera have been identified in Kazan. Among them were two species from the Red Book of RT: Cicindela germanica Linneus, 1758 and Carabus convexus Fabricius, 1775. The greatest number of species are represented by the genus: Amara -- 18, Harpalus -- 16, the genus Bembidion and Pterostichus are represented by 7 species, Poecilus and Calathus by 5 species. Ground beetles assemblages clearly responded to varying degrees of recreation by changing the biotopic distribution and ecological structure: the emergence of species of superdominants, a decrease in the abundance of zoophages, an increase in the proportion of stratobionts, and the presence of types of recreation indicators. The results we obtained fully confirm the literature data. The structure of the carabid complex in Kazan testifies to a favorable ecological situation in the city in average. However, individual biotopes with different carabidological indicators gave conflicting results, which indicated the need to include additional parameters for a more unambiguous assessment. The dynamic density of the karabid complex in the industrial zone is the smallest in the city and is 94.2 ind./10 trap-days, in the residential zone -- 1572 ind./10 trap-days, the highest in the recreation area -- 202 ind./10 trap-days.

In the Sovetsky district, ground beetles were represented by 58 species $(62.4 \%$ among the whole Kazan fauna) of 28 genera. With a relatively high species diversity of ground beetles in the city, 11 species numerically dominated: Pterostichus melanarius Illiger, 1798 (12.4 \%), Poecilus versicolor Sturm, 1824 (10.3\%), Harpalus rufipes Dejen, 1828 (9.5 \%), Carabus cancellatus (9.2\%) Illiger, 1798, Carabus granulatus Linneus, 1738 (5.6\%), Poecilus cupreus (4.4\%), Bembidion properans Stephens, 1829 (4.1\%), Poecilus lepidus Leske, 1785 (3.8 \%), Harpalus serripes Quensel, 1828 (3.8\%), Amara aenea Dej Ceer, 1774 (3.5 \%), Pterostihus oblongopunctatus Fabricius, 1787 (2.7\%). The dynamic density of the carabide in the considered area differed in zones from the general picture of the city. So, its highest value was noted in the residential zone (56 ind. / 10 trap -days), which was 2.2 times higher than in the industrial zone and 4.1 times higher than in the recreation zone (respectively 25.6 and 13,8 ind. / trap-days.). The species richness of ground beetles was also twice as high as in other zones (74 species versus 33 ). 
According to the type of biotope, the highest average dynamic density was observed in forest belts (62 ind. / 10 trap-days) and was localized in green zones around houses (50.7 ind. / 10 trap-days). Half as much on lawns (33 ind. / 10 trap. -days), then in squares, parks (27.2 ind. / 10 trap-days) and meadows (20.7 ind. / 10 trap -days.). High species diversity was noted in parks and squares (30 species), less in green areas around houses (24), forest belts (22), lawns (20) and meadows (13).

In all the years of research, 147 species of ground beetles of 14 subfamilies of 19 tribes of 40 genera were found in Kemerovo. In the first section, in the square of the coking plant, 40 species of ground beetles of 16 genera were noted and the lowest dynamic population density of ground beetles among all model plots was 7.3 ind./10 trap -days. The area was dominated by meadow-steppe species -- $35 \%$ (14 species) of species composition. Meadow and forest species accounted for $22.5 \%$ each, steppe and coastal -- 5 \% each ( 2 species each), eurytopic species -- 10 \% (4 species). The meadow-steppe species of ground beetles dominated -- Calathus erratus (Sahlb.), which accounted for $20.7 \%$ of ground beetles fees at the site, and Harpalus rufipes (Deg.) -- $10.8 \%$. The number of meadow species Badister bullatus (Schrnk) was high -- $8.4 \%$.

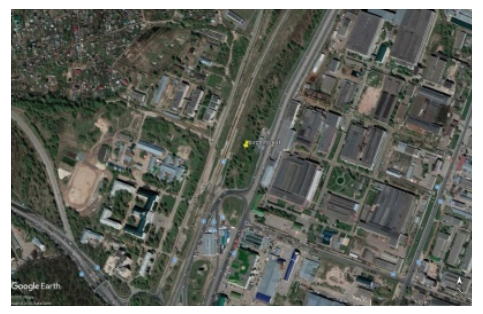

1

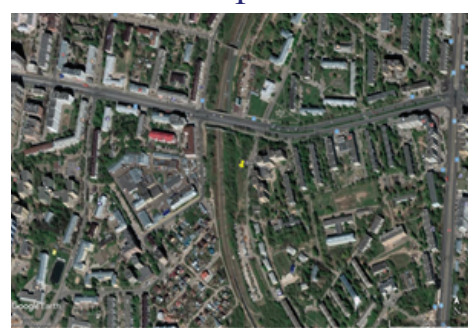

3

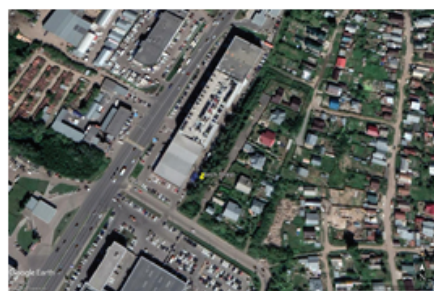

2

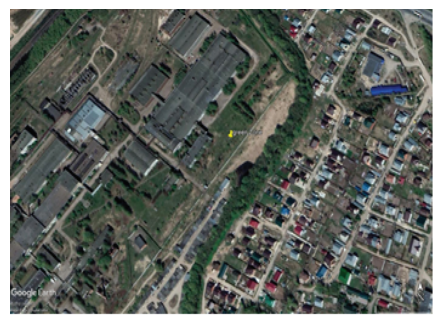

4

Figure 6: Plots 1--4 are in the Soviet district of Kazan

In the second section, in the sanitary protection zone of SDS Azot, a habitat of 64 species of ground beetles of 24 genera was established. The dynamic population density of ground beetles was 22.0 ind/10 trap-days. The population of ground beetles of the site was represented by the following groups: meadow (21 species, $30.9 \%$ ), forest (17; 25), meadow-steppe (13; 19.1), coastal $(8 ; 11.8)$, eurytopic $(5 ; 7,4)$ and steppe $(4 ; 5,9)$. A high number was demonstrated by the eurytopic Poecilus versicolor (Sturm) (35.8\%), 


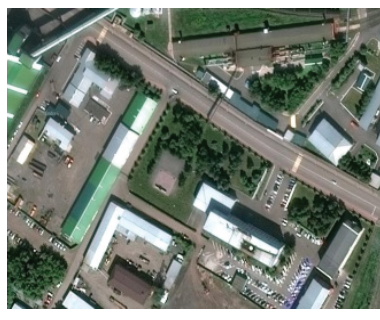

A

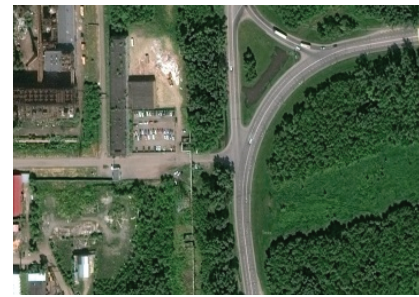

B

Figure 7: Sections 1--2, located in the industrial zone of the Zavodsky industrial center in Kemerovo: A -PJSC Coke (coking plant) B -- sanitary protection zone of SDS Azot JSC.

the forest species Carabus regalis Fisch. (15.6\%), meadow species Amara communis (Pz.) (12.2).

The smallest species richness of ground beetles was observed at site 3 (Regional Library) in the residential zone of the Central District -- 31 species of ground beetles of 14 genera. The dynamic population density of ground beetles was 27.7 ind/10 tra -days. At the same time, almost half of the fees amounted to the superdominant Pterostichus melanarius (III.), with an average dynamic density of $13.7 \mathrm{ind} / 10$ trap-days (49.5\% of fees). Harpalus rufipes (Deg.) (7.6 \%), Amara communis (Pz.) (5.7), Poecilus versicolor (Sturm) (4.9) were common also. The species abundance ass dominated by meadow species (12 species), which accounted for $38.7 \%$ of the total number of species on the site. The lesser number of species were forest species ( 9 species, $29 \%$ ), meadowsteppe $(5,16.2)$, eurytopic $(4 ; 12.9)$, coastal $(1 ; 3.2)$. The high abundance in the lawn in the residential area of a very large forest species Carabus regalis Fisch. was noted, which accountd for $18.4 \%$ of the fees on that site.

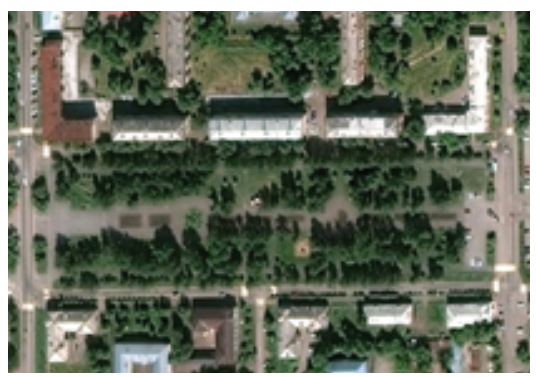

Figure 8: Section 3, located in the residential zone of the Central District of Kemerovo, near the regional library.

The recreational zone of the city, despite its active use by the population for recreation, was distinguished by the greatest species diversity of ground beetles. In the pine forest (plots 4--6), 95 species of ground beetles of 30 genera were noted, 12 of them are new for the city of Kemerovo: Carabus obovatus Fisch., Pterostichus haptoderoides Tschit. Pterostichus dilutipes (Motsch.), Amara bamidunyae Bates, Amara plebeja (Gyll.), Agonum subtruncatum (Motsch.), Bradycellus caucasicus (Chaud.), Harpalus modestus 
Dej., Harpalus xanthopus Gemm. et Har., Microlestes maurus (Sturm), Philorizus sigma (Rossi), Lebia cyanocephala (L.).

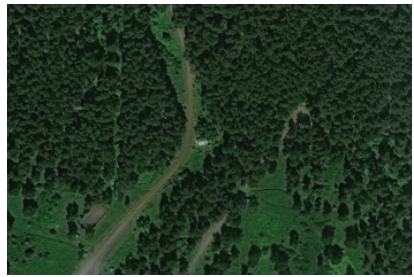

Site 4

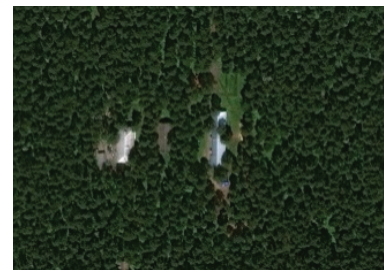

Site 5

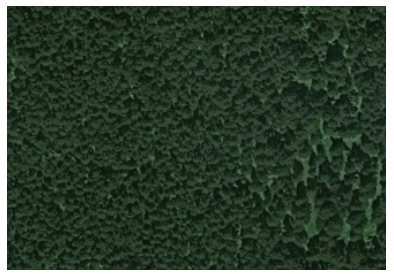

Site 6

Figure 9: Sites 4--6, located in the recreational zone of Kemerovo, in a pine forest.

The dynamic population density of ground beetles of the pine forest of Kemerovo averaged $21.7 \mathrm{ind} / 10$ trap-days. In general, the structure of the boron population ass formed mainly by meadow (26 species, $26.3 \%$ ) and forest (25; 26.3 respectively) species. In addition to representatives of those biotopic groups in boron, meadowsteppe (15 species; $15.8 \%$ ), coastal (13; 13.7), steppe (11; 11.6), and eurytopic (5; 5.3) species were noted. However, the species composition of ground beetles of model areas was different. On site 4, often visited by people, 67 species of ground beetles were noted, on site 5 (sports ground) -- 54 and site 6 (central part of the forest) -- 57 species. The greater species richness on the site, frequently visited by people, was due to the greater rarefaction of the forest. The species composition of ground beetles there was mainly formed by species of open habitats. In that area, the meadow, meadowsteppe and steppe species accounted for $56.7 \%$ of all species in total. For comparison, on plots 5 and 6 , those species were 42.6 and $43.9 \%$, respectively. $28.4 \%$ fell on forest species at site 4, 38.9 and $35.1 \%$ at sites 5 and 6 . In all areas of boron, forest species Carabus regalis Fisch. demonstrated a high dynamic density (on average, 8.8 ind/ 10 trap -days.), C. aeruginosus Fisch. (1,3), C. henningi Fisch. (1,1), Pterostihus magus Mnnh. $(2,9)$. In addition to those species, section 4 showed high abundance of the meadow species Calathus melanocephalus (L.), eurytopic Poecilus versicolor (Sturm). In areas 5 and 6, the forest species Pterostihus oblongopunctatus (F.), was distinguished by a high number, and in section 5 -- the eurytopic Poecilus versicolor (Sturm).

\section{Conclusion}

The analysis of the Carabid fauna of the three cities revealed general trends in its structure. Ground beetles assemblages clearly respond to varying degrees of recreation by changing the biotopic distribution and ecological structure: the emergence of species of superdominants, a decrease in the abundance of zoophages, an increase in the 
proportion of stratobionts, and the presence of types of recreation indicators. Due to the high mosaicity of the urban environment, the composition of the herpetobia also changes to a large extent, forming a complex, non-uniformly distributed carabid complex of urbanized territories. The greatest species diversity is observed in forest belts, parks, green areas of cities. An increase in the area of anthropogenic landscapes leads to a decrease in the proportion of near-water hygrophilous, forest species and an increase in meadow-field, steppe meso- and xerophilia with a mixed type of food.

In transformed biotopes, eurytopic ruderal species increase their numbers and act as dominants and superdominants. The highest average dynamic density was observed in forest belts and green zones, the smallest was noted in the industrial zone, the ruderal species increased their numbers and became super dominant. The poly dominant structure of carabid complexes was replaced by oligodominant.

The main pattern in the formation of Ground Beetles assemblages in urban biocenoses is that they are populated primarily by polyzonal species with a wide ecological plasticity, as well as by migrants from the surrounding suburban landscapes.

\section{References}

[1] Avtaeva, T.A., Zaharov, N.E. (2018) Analiz vozmozhnostej ispol'zovaniya dannyh GOOGLE EARTH dlya ocenki dinamiki sostoyaniya gorodskih biotopov $v$ period s 2003 po 2017 g. v gorode Groznom. Materialy II mezhdunarodnoj nauchnoprakticheskoj konferencii "Zelenaya infrastruktura gorodskoj sredy: sovremennoe sostoyanie i perspektivy razvitiya". Voronezh. pp. 3--7.

[2] Maxwell, J.C. (1892). A Treatise on Electricity and Magnetism, 3rd ed., vol. 2. Oxford: Clarendon, pp. 68--73.

[3] Afonina, G.G., YAkovleva, G.I. (1997). Rastitel'nost' yuzhnogo makrosklona Rudnichnogo bora (g. Kemerovo). Ehkologiya-Bezopasnost'-Zhizn', pp. 34--35. Kemerovo.

[4] Bajmaganbetova, G.A. Golubeva, E.I. Kosmicheskie snimki dlya kartografirovaniya i monitoringa sostoyaniya zelenogo karkasa g. Astany. Retrieved from: https: //docplayer.ru/54204340-G-a-baymaganbetova-1-e-i-golubeva-2.

[5] Singh, B.M., Kuznecov, A.V., Kumari, Ch.K., Kupriyanov, A.V. (2015). Metody analiza sputnikovyh izobrazhenij dlya issledovaniya urbanizacii i zemlepol'zovaniya $v$ period s 1975 po 2015 g. v g. Samare. Komp'yuternaya optika, vol. 39, no. 5, pp. 818--823.

[6] Vazhenina, N.V, Buhkalo, S.P., Lyashchev, A.A. (2015). Osobennosti formirovaniya sostava i struktury fauny zhuzhelic goroda Tobol'ska. Nauchnye vedomosti, Ser. 
Estestvennye nauki, vol. 32, no. 15(212), pp. 101--108.

[7] Zinov'ev, E.V., Parhachyov, A.A. (2017). Harakteristika ehlementarnoj fauny zhestkokrylyh (Insecta: Coleoptera) uchastka gorodskoj zastrojki Ekaterinburga. Fauna Urala i Sibiri, no. 1, pp. 63--83.

[8] Isaeva, N.I. (2012). EHkologo-faunisticheskij obzor naseleniya zhuzhelic (Coleoptera, Carabidae) urbolandshaftov goroda Samary. Izvestiya Samarskogo nauchnogo centra Rossijskoj akademii nauk, vol. 14, no. 1, pp. 132--138.

[9] Ozdorovlenie okruzhayushchej sredy g. Kazani na 2004--2008 gg. (2004). Kazan', pp. 70.

[10] Puchkov, O.V., Nikolenko, N.Yu., Garkusha, I.A. (2017). Ehkologo-faunisticheskij obzor zhuzhelic triby Pterostichini (Coleoptera, Carabidae) parkovyh urbocenozov severnoj i vostochnoj Ukrainy, biologiya i valeologiya, no. 19, pp. 69--78.

[11] Cherdinceva, T.M., A.A. CHerdincev, Fauna zhuzhelic (Coleoptera, Carabidae) ehkologo-funkcional'nyh zon goroda Orenburga. Vestnik Orenburgskogo gosudarstvennogo pedagogicheskogo universiteta. Retrieved from: http://www. vestospu.ru. ISSN 2303-9922

[12] Ruchin, A.B., Alekseev, S.K., Artaev, O.N. (2017). Species composition of Ground beetles (Coleoptera, Carabidae) in Saransk. Acta Biologica Sibirica, no. 3(3), pp. 86--96.

[13] Suhodol'skaya, R.A., Timofeeva, G.A., Habibullina, N.R. (2009). Fauna i populyacionnye harakteristiki zhuzhelic g. Kazani. Uchenye zapiski Kazanskogo gosudarstvennogo universiteta, Ser. Estestvennye nauki, vol. 151, book 2, pp. 145-150. 